\title{
Acute Chest Pain in Sickle Cell Disease- Its Unusual Cause
}

Jagabandhu Ghosh ${ }^{1^{*}}$ and Joydeep Ghosh ${ }^{2}$

${ }^{1}$ Department of Paediatrics, I.P.G.M.E.R \& S.S.K.M Hospital, Kolkata, West Bengal, India

${ }^{2}$ Department of Biotechnology, Heritage Institute of Technology, Kolkata, West Bengal, India

"Corresponding author: Jagabandhu Ghosh, Consultant Pediatrician, Ex-Professor \& HOD, I.P.G.M.E.R, Ushashi Housing Society, 245 Vivekananda Road, Kolkata-700006, India, Tel: 9434239336; E-mail: jbghosh@yahoo.com

Received date: Nov 18, 2014, Accepted date: Dec 31, 2014, Publication date: Jan 05, 2015

Copyright: () 2015 Ghosh J, et al. This is an open-access article distributed under the terms of the Creative Commons Attribution License, which permits unrestricted use, distribution, and reproduction in any medium, provided the original author and source are credited.

\section{Abstract}

Acute chest pain is the second most common cause of hospitalisation in sickle cell disease. A case of sickle cell disease is reported here with unusual feature and an unusual cause for acute chest pain.

Keywords: Acute chest pain; Sickle cell disease

\section{Introduction}

Acute chest pain (ACP) in Sickle Cell Disease (SCD) is usually caused by Acute Chest Syndrome (ACS), a pulmonary illness defined by a new infiltrate on chest radiograph in combination with at least one clinical sign or symptom: chest pain, cough, wheezing, tachypnea and /or fever $\left(>38^{\circ} \mathrm{c}\right)$ [1]. The commonest precipitating factors include infection, pulmonary fat embolism and pulmonary infarction.ACS in SCD can occur secondary to infectious and non-infectious events [2] Febrile illness, surgery, and painful event in previous two weeks are prodromes of ACS [3]. A case of sickle cell disease is reported here with unusual feature and unusual cause for ACS without fulfilment of criteria for ACS.

\section{Case Report}

An 8-year-old girl child was admitted with complaints of severe chest pain, swelling and pain over right elbow joint for two days prior to hospitalisation. Twenty four hours after onset of illness she developed pain and swelling over right arm. The nature of chest pain was excruciating, diffuse affecting both sides without any relation to posture or respiration. It was not associated with swelling and redness over the affected area. There was no history of fever, trauma or bleeding manifestation. About four years back patient had an attack of fever with tiredness and generalised weakness for which she received one unit of packed cell transfusion. About one year back she had an episode of back pain associated with swelling and pain over few big joints involving knee, ankle and wrist which subsided after one unit of packed cell transfusion. No significant family history was available.

On physical examination she had moderate degree anaemia, body weight $16 \mathrm{~kg}$, height $115 \mathrm{~cm}$. There was no jaundice. Her abdominal examination revealed liver $4 \mathrm{~cm}$ below right costal margin, firm in consistency. Spleen was $2 \mathrm{~cm}$ palpable below left costal margin, firm in consistency, nontender, sharp margin. Right elbow joint was swollen, tender, and hot without erythema of overlying skin. Painful limitation of movement of right elbow joint was also observed. Front of right mid arm showed tender swelling of $2 \mathrm{~cm} \times 2 \mathrm{~cm}$ size, soft and ill defined margin. Her respiration rate was 24/minute; pulse rate was 90/minute. Respiratory system examination revealed vesicular breath sound without any crepitation, wheeze or any plural rub. Other system examination did not show any abnormality.

Laboratory investigations revealed haemoglobin of $8 \mathrm{gm} / \mathrm{dl}$, total leucocyte count $9000 / \mathrm{cu} \mathrm{mm}$ with $70 \%$ polymorphs, $25 \%$ lymphocytes, $3 \%$ eosinophills, $2 \%$ monocytes. Platelet and reticulocyte count were respectively $1.9 \mathrm{lacs} / \mathrm{cu} \mathrm{mm}$ and $4 \%$. Peripheral smear showed normocytic and normochromic type of anaemia. The ESR and Creactive protein was $10 \mathrm{~mm}$ in the 1 st hour and $0.6 \mathrm{mg} / \mathrm{dl}$ respectively. Her blood culture did not grow any organism. Bronchoalveolar lavage fluid analysis could not be done. HPLC study of the patient showed HbS-71.5\%, HbF-16\%, HbA2-6.3\% and $\mathrm{HbA}-6.2 \%$. Her sickling test was positive. HPLC of her brother was normal. Her mother and father showed evidence of $\beta$-Thalassaemia trait and sickle cell anaemia trait respectively by HPLC. Her coagulation profile (P.T. and A.P.T.T) were normal. Her chest X-ray showed no abnormality. High resolution computed tomography of chest showed no abnormality. Electrocardiogram was within normal limit. Serum creatin kinase (CK) level was elevated (450 IU/L; normal $<160$ IU/L). Ultrasonography of right elbow joint showed increased joint space, echogenic collection with mild synovial thickening and regular smooth bone surface. Arthocentesis and joint fluid analysis could not be done because parents did not give consent in view of severe pain. Patient was treated with I.V. ceftriaxone, naproxene and one unit of concentrated R.B.C transfusion. She showed rapid improvement of pain over chest, arm and elbow within 2-3 days of treatment. After two weeks of discharge from hospital she was followed up at outpatient department when she showed no evidence of arthritis and swelling over arm. She had no chest pain also. Her $\mathrm{Ck}$ value came down to normal.

\section{Discussion}

Sickle cell anaemia, homozygous HbS, occurs when both $\beta$-globin genes have the sickle cell mutation. Sickle cell disease refers not only to individuals with sickle cell anaemia, but also to compound heterozygotes when one $\beta$-globin gene mutation includes the sickle cell mutation and the $2 \mathrm{nd} \beta$-globin includes a gene mutation in the $\beta$ globin gene other than the sickle cell mutation,such as mutations associated with $\mathrm{HbC}, \mathrm{Hb} \beta$-thalassemia, $\mathrm{HbD}$, and $\mathrm{HbO}$ Arab [4]. The index patient was diagnosed as sickle $\beta+$-thalassemia based on clinical profile and HPLC study. The pathogenesis of ACS in sickle cell disease 
Page 2 of 2

is complex. The commonest causes include infection, pulmonary fat embolism and pulmonary infarction $[5,6]$. Doubt was casted in favour of infection as the cause for ACP in view of the fact that the present case did not show fever, leucocytosis. Pulmonary fat embolism and pulmonary infarction were excluded by H.R.C.T and skiagram of chest though bronchoscopy could not be done. The present case did not fulfil the criteria of ACS to account for ACP in view of absence of infiltrate on skiagram of chest. Therefore severe chest pain in association with pain and swelling of right mid arm was suspected to be due to muscular inflammation. This was supported by elevated serum CK level. Vasoocclusive crisis of different types is hallmark and common manifestation of sickle cell disease. Vascular occlusion is caused by sickle shaped red cells leading to inflammation and/or necrosis of the affected structure or organ of the body. Earlier myonecrosis in sickle cell anaemia has been reported by Tageja et al in an adult patient [7]. Very few cases have been reported about myositis/ myonecrosis causing chest pain or limb pain in sickle cell anaemia previously more so in paediatric age group. The swelling over middle of right arm was an unusual presentation of this case. To the best of my knowledge this feature was not reported in the literature previously.

Joint swelling in SCD is mostly considered to be caused by sepsis which is fairly common in this illness, unless proved otherwise. In the present case it is thought to be caused by vasoocclusive inflammatory changes of synovium in absence of infection because the patient did not have fever and leucosytosis. This was further supported by the fact that joint symptoms and signs dramatically improved within 2-3 days.

So, from the present case it is thought that myositis, the pathogenetic mechanism of which is vasoocclusive phenomenon, can sometimes be the cause of ACP in SCD. Similarly the synovitis, the cause for joint swelling, may also be mediated by vasoocclusive crisis and not the infection. This case report, therefore, highlights the need for future study in establishment of relation of myositis with ACP in SCD.

\section{State of Informed Consent}

Parents were informed about the suitability of publication of the case in the journal. They gave verbal consent in this regard.

\section{References}

1. Platt OS (2000) The acute chest syndrome of sickle cell disease. N Engl J Med 342: 1904-1907.

2. Agarwal MB (2003) Advances in management of sickle cell disease. Indian J Pediatr 70: 649-654.

3. Walters MC, Nienhuis AW, Vichinsky E (2002) Novel therapeutic approaches in sickle cell disease. Hematology Am Soc Hematol Educ Program .

4. Baun MRD, Vichinsky E. (2008) Hemoglobinopathies. Nelson Textbook of Pediatrics. Saunders, Philadelphia : 2025-2038.

5. Walters MC, Nienhuis AW, Vichinsky E (2002) Novel therapeutic approaches in sickle cell disease. Hematology Am Soc Hematol Educ Program .

6. Rosse WF, Narla M, Petz LD, Steinberg MH (2000) New Views of Sickle Cell Disease Pathophysiology and Treatment. Hematology Am Soc Hematol Educ Program .

7. Tageja N, Racovan M, Valent J, Zonder J (2010) Myonecrosis in sickle cell anemia-overlooked and underdiagnosed. Case Rep Med 2010: 659031. 